\title{
Assessment of Muscarinic Receptor Concentrations in Aging and Alzheimer Disease With $\left[{ }^{11} \mathrm{C}\right]$ NMPB and PET
}

\author{
JON-KAR ZUBIETA, ${ }^{1,2 *}$ ROBERT A. KOEPPE, ${ }^{2}$ KIRK A. FREY, ${ }^{2,3}$ MICHAEL R. KILBOURN, ${ }^{2}$ \\ THOMAS J. MANGNER, ${ }^{2}$ NORMAN L. FOSTER, ${ }^{3}$ AND DAVID E. KUHL ${ }^{2}$ \\ ${ }^{1}$ Department of Psychiatry, The University of Michigan, Ann Arbor, Michigan \\ ${ }^{2}$ Department of Internal Medicine (Division of Nuclear Medicine), The University of Michigan, \\ Ann Arbor, Michigan \\ ${ }^{3}$ Department of Neurology, The University of Michigan, Ann Arbor, Michigan
}

\begin{abstract}
KEYWORDS acetylcholine; neurodegeneration; receptor quantification; dementias
\end{abstract}
ABSTRACT Cerebral cholinergic deficits have been described in Alzheimer disease $(\mathrm{AD})$ and as a result of normal aging. At the present time, there are very limited options for the quantification of cholinergic receptors with in vivo imaging techniques such as PET. In the present study, we examined the feasibility of utilizing $\left[{ }^{11} \mathrm{C}\right] \mathrm{N}$-methyl-4piperidyl benzilate (NMPB), a nonselective muscarinic receptor ligand, in the study of aging and neurodegenerative processes associated with cholinergic dysfunction. Based on prior data describing the accuracy of various kinetic methods, we examined the concentration of muscarinic receptors with $\left[{ }^{11} \mathrm{C}\right] \mathrm{NMPB}$ and PET using two- and threecompartment kinetic models. Eighteen healthy subjects and six patients diagnosed with probable $\mathrm{AD}$ were studied. Pixel-by-pixel two-compartment model fits showed acceptable precision in the study of normal aging, with comparable results to those obtained with a more complex and less precise three-compartment model. Normal aging was associated with a reduction in muscarinic receptor binding in neocortical regions and thalamus. In $\mathrm{AD}$ patients, the three-compartment model appeared capable of dissociating changes in tracer transport from changes in receptor binding, but suffered from statistical uncertainty, requiring normalization to a reference region, and therefore limiting its potential use in the study of neurodegenerative processes. After normalization, no regional changes in muscarinic receptor concentrations were observed in AD. Synapse 39:275-287, 2001. ๑ 2001 Wiley-Liss, Inc.

\section{INTRODUCTION}

Cholinergic deficits, with marked reductions in the enzymes choline acetyltransferase and acetylcholinesterase, and cholinergic neuronal loss have been reported even at early stages of Alzheimer disease $(\mathrm{AD})$, both in biopsied tissue and in postmortem studies (Davies and Maloney, 1976; White et al., 1977; Perry et al., 1978; Bowen et al., 1982; Sims et al., 1983; DeKosky et al., 1992). Reductions in cholinergic function may then be responsible for some of the deficits encountered in this illness. Specifically, both neuronal loss and choline acetyltransferase activity have been correlated with measures of cognitive function in $\mathrm{AD}$ patients (Perry et al., 1978; Wilcock et al., 1982; DeKosky and Scheff, 1990; Terry et al., 1991; DeKosky et al., 1992).

Some controversy exists regarding the status of cholinergic receptors in $\mathrm{AD}$. In vitro autopsy and biopsy findings point towards unaltered total muscarinic receptor densities in $\mathrm{AD}$, compared with control autop- sies (Davies and Verth, 1978; Perry et al., 1978; Sakurada et al., 1990; Schroder et al., 1991; DeKosky et al., 1992). Conversely, brain imaging studies performed with $\left[{ }^{123} \mathrm{I}\right]$ quinuclidinyl benzilate $(\mathrm{QNB})$ and SPECT in living subjects diagnosed with probable $\mathrm{AD}$ have described focal reductions in $\left[{ }^{123} \mathrm{I}\right] \mathrm{QNB}$ distribution in neocortical regions (Holman et al., 1985; Weinberger et al., 1991, 1992; Wyper et al., 1993). In one of these studies, focal reductions in $\left[{ }^{123} \mathrm{I}\right] \mathrm{QNB}$ binding were more extensive than those encountered with $\left[{ }^{18} \mathrm{~F}\right] 2$-fluoro-2-deoxyglucose (FDG), and it was proposed that the cholinergic marker would be a more sensitive measure of the extent of $\mathrm{AD}$ than the metabolic maps (Weinberger et al., 1992). Data recently

\footnotetext{
Contract grant numbers: NS-15655 and DE-FG02-ER60561.

*Correspondence to: Jon-Kar Zubieta, MD, PhD, The University of Michigan, Neuroscience Building, 1103 East Huron Street, Ann Arbor, MI 48104-1687. E-mail: zubieta@umich.edu

Received 3 July 2000; Accepted 25 July 2000
} 
presented by another group, using $\left[{ }^{11} \mathrm{C}\right] \mathrm{N}$-methyl-4piperidyl benzylate (NMPB) and PET, with a graphical analysis approach, using cerebellum as input function, also showed reductions in tracer distribution in the parietal cortex of patients diagnosed with probable $\mathrm{AD}$ (Ichimiya et al., 1995).

A similar situation has been encountered in studies exploring cholinergic changes associated with normal aging. An increased sensitivity to the effects of muscarinic antagonists have been described with advancing age in humans (Molchan et al., 1992), suggesting agerelated alterations in the number or function of cholinergic receptors. In vitro binding studies have found moderately decreased or unchanged total populations of muscarinic cholinergic receptors during normal aging in human postmortem samples (Giacobini, 1990; Schroder et al., 1991; Nordberg et al., 1992). In experimental animals, regionally selective alterations have been reported, with some studies describing moderate reductions in muscarinic receptor number in neocortical regions, basal ganglia, thalamic, and pontine nuclei (Biegon et al., 1988), and others finding no significant change with age (Pearce et al., 1992; Wang et al., 1992). Larger declines in radioligand binding have been described using brain imaging techniques. In a PET study with $\left[\mathrm{N}-{ }^{11} \mathrm{C}-\right.$ methyl]-benztropine, Dewey et al. (1990) reported reductions in specific radioligand binding as a function of age in neocortical and basal ganglia regions, but unchanged distribution in thalamus, hippocampus, or cerebellum. Using $\left[{ }^{11} \mathrm{C}\right] \mathrm{NMPB}$ and a graphical analysis method with cerebellum as input function, Suhara et al. (1993) described very large decreases in radioligand distribution in all brain regions studied, which included neocortical, basal ganglia, and other subcortical structures. A subsequent publication, in which young and elderly subjects were studied with the nonselective muscarinic receptor antagonist $\left[{ }^{11} \mathrm{C}\right]$ tropanyl benzylate (TRB) and PET, showed relatively minor reductions in frontal cortical binding, and increases in the cerebellum and midbrain (Lee et al., 1996).

While it is possible that some differences between autopsy and receptor imaging studies with PET or SPECT may exist because of postmortem changes (Brady and Mufson, 1990), methodological issues associated with muscarinic receptor quantification with PET or SPECT are likely to be responsible for some of these discrepancies. The success of SPECT and PET tomographic analysis to obtain accurate binding information for the muscarinic system has been hampered by the in vivo kinetic behavior of the different radiotracers employed, which have included $\left[{ }^{11} \mathrm{C}\right]$ scopolamine (Frey et al., 1992), $\left[{ }^{11} \mathrm{C}\right]$ tropanyl benzilate (Koeppe et al., 1994), $\left[{ }^{11} \mathrm{C}\right]$ benztropine (Dewey et al., 1990a,b), [ $\left.{ }^{123} \mathrm{I}\right]$-3-quinuclidinyl-4-iodobenzilate (Eckelman et al., 1984; Sawada et al., 1990), and $\left.{ }^{[23} \mathrm{I}\right]$ iododexetimide (Müeller-Gärtner et al., 1992). Typically, these agents display long equilibration times due to slow ligand-receptor dissociation and/or overly rapid binding relative to the rate of ligand transport across the blood-brain barrier back out of the brain. Accurate quantification of regional receptor densities becomes difficult under these circumstances. Slow dissociation of the ligand from receptor sites precludes using equilibrium modeling or single scan analysis, since true equilibration is not achieved during the scanning period. When the rate of binding is too rapid (relative to the rate of transport), this results in a delivery-limited condition in which the receptor measures become sensitive to changes in blood flow (Koeppe, 1990; Koeppe et al., 1994). Additionally, biases are introduced into the measurements when it is assumed that cerebellar concentrations of tracer are equivalent to free tracer concentration in other brain regions (Ichimiya et al., 1995, Suhara et al., 1993, 1994). This is due to a significant degree of specific binding in the cerebellum, and free tracer concentrations that may vary regionally ( $\mathrm{Zu}-$ bieta et al., 1998). Furthermore, as binding density increases the concentration of free ligand decreases and, thus, even with equivalent free + nonspecific distribution volumes, the level of free tracer in basal ganglia will be considerably lower than in cerebellum.

We have developed a radiolabeled muscarinic receptor antagonist, $\left[{ }^{11} \mathrm{C}\right] \mathrm{NMPB}$ (Mulholland et al., 1988), which in human studies with PET (Zubieta et al., 1998) appears to present more favorable kinetic properties than prior compounds (Koeppe et al., 1992). In these initial studies, various quantification models were evaluated for their ability to provide unbiased estimates of receptor density. On the basis of those observations, only models utilizing arterial blood sampling and kinetic modeling were able to accurately dissociate changes in tracer transport from receptor binding. A simplified, pixel-by-pixel implementation of a weighted-integral two-compartment model was deemed adequate for the estimation of receptor binding when tracer transport was not severely altered. When tracer delivery was modified by relatively large changes in regional cerebral blood flow ( $\mathrm{rCBF}$ ), a more complex three-compartment model was necessary to isolate changes in tracer transport from receptor binding measures (Zubieta et al., 1998).

In the present report, both approaches were utilized for the quantification of muscarinic receptor binding with $\left[{ }^{11} \mathrm{C}\right] \mathrm{NMPB}$ and PET. In the case of subjects diagnosed with probable $\mathrm{AD}$, large reductions in cerebral blood flow and metabolism have been reported in brain regions most affected by the disease (Frackowiak et al., 1981; Benson et al., 1983; Haxby et al., 1990; Bonte et al., 1993). Under these conditions, the simplified model would not be likely to completely isolate changes in ligand transport from changes in actual receptor binding. To reduce the possibility that perceived changes in radioligand distribution were being induced by alter- 
ations in its delivery, both a pixel-by-pixel two-compartment and three-compartment tracer kinetic models were assessed for the analysis of data from $\mathrm{AD}$ subjects.

\section{MATERIALS AND METHODS Subjects}

Eighteen healthy volunteers of ages ranging from 21-83 years old (mean $\pm 1 \mathrm{SD}, 40 \pm 23$ ), 11 males, seven females, were recruited via local newspaper advertisements and studied after undergoing physical and neurological examinations. The subjects had no significant medical, neurological, or psychiatric history, or family history of neurological or psychiatric illness in first-degree relatives. They were also screened for drug or alcohol use, smoking, or excessive consumption of caffeine. A subgroup of six older ageand gender-matched (69 \pm 10 years old) healthy volunteers were selected for comparison with patients diagnosed with $\mathrm{AD}$. The studies were approved by the University of Michigan Institutional Review Boards governing the use of human subjects and the use of radionuclides in human research, and written informed consent was obtained prior to all experimental procedures.

A group of six subjects diagnosed with probable $\mathrm{AD}$ (65 \pm 10 years old, four females, two males) were recruited from a pool of patients included in a longitudinal follow-up study at the Alzheimer's Disease Research Center at the University of Michigan. They met ADRDA/NINCDS (McKhann et al., 1984) and DSMIII-R criteria (APA, 1987) for probable Alzheimer's disease. All six subjects underwent neuropsychological testing and neurological examinations prior to scanning, which supported the clinical diagnosis. At the time of PET scanning, Mini-Mental Status scores were $17 \pm 3$ (range 11-22), Hachinski Ischemic Scale scores were $1 \pm 1$ (range 0-2), and Hamilton Depression Rating Scale scores were below 4 in all cases. Additionally, all patients displayed a typical biparietal hypometabolic pattern of AD in $\left[{ }^{18} \mathrm{~F}\right] \mathrm{FDG}$ PET scans, which were performed prior to scheduling receptor imaging with $\left[{ }^{11} \mathrm{C}\right] \mathrm{NMPB}$.

\section{Scanning procedures}

Radial artery and antecubital vein catheters were placed for collection of arterial blood samples and for radiotracer administration, respectively. The subjects were then positioned supine in the gantry of a CTI/ Siemens 931/08-12 scanner. This tomograph acquires 15 contiguous slices, covering a $\sim 10 \mathrm{~cm}$ field of view with a reconstructed in-plane resolution of $\sim 7-8 \mathrm{~mm}$ at FWHM. Subject positioning was standardized using laser beams, with the canto-meatal line selected as imaging plane. Each scan was initiated after the intravenous bolus administration of no-carrier-added, high specific activity $(>1,000 \mathrm{Ci} / \mathrm{mmol})\left[{ }^{11} \mathrm{C}\right] \mathrm{NMPB}$ (Mulholland et al., 1988). Two different dosing protocols were utilized. Young healthy controls received $20 \pm 2 \mathrm{mCi}$ $\left.{ }^{[1} \mathrm{C}\right] \mathrm{NMPB}$. Elderly healthy controls $(\mathrm{n}=6)$ and patients diagnosed with $\mathrm{AD}$ received $39 \pm 3 \mathrm{mCi}$, after $\left[{ }^{11} \mathrm{C}\right] \mathrm{NMPB}$ dosimetry was reevaluated. All subjects were scanned with eyes and ears unoccluded in a room with dimmed light and background white noise.

A sequence of 18 PET scans were acquired covering $110 \mathrm{~min}(2 \times 30 \mathrm{sec}, 4 \times 1 \mathrm{~min}, 2 \times 2.5 \mathrm{~min}, 2 \times 5 \mathrm{~min}$, $7 \times 10 \mathrm{~min}, 1 \times 20 \mathrm{~min}$ ). Blood samples were withdrawn from the radial artery, as rapidly as possible for the first 2 min of the scanning period, and then at 2.5, $3,4,5,7.5,10,15,20,30,45,60,85$, and $110 \mathrm{~min}$ postinjection.

Patients diagnosed with $\mathrm{AD}$ also underwent $\left[{ }^{18} \mathrm{~F}\right] \mathrm{FDG}$ scans approximately 1 week prior to the receptor studies to support the clinical diagnosis. Ten $\mathrm{mCi}$ of $\left[{ }^{18} \mathrm{~F}\right] \mathrm{FDG}$ were injected intravenously. Beginning 30 min postinjection, two sets of interleaved static images were obtained. The FDG activity maps were subsequently reoriented to match the parametric $\mathrm{K}_{1}$ maps obtained from the NMPB scans by using an image coregistration computer algorithm (Minoshima et al., 1992).

\section{Metabolite correction of the arterial input function}

A total of 14 plasma samples were analyzed for the presence of metabolites. A rapid Sep-Pak C18 cartridge, reverse-phase chromatographic technique was utilized (Zubieta et al., 1998). The arterial blood was centrifuged and the plasma applied to the column. A metabolite fraction was obtained by washing the column with $9 \mathrm{ml}$ of a $36 \%$ ethanol/sodium borate buffer ( $\mathrm{pH} 10)$ solution. The NMPB fraction was then eluted with $5 \mathrm{ml} 100 \%$ ethanol. The separation was corrected for the loss of NMPB in the metabolite fraction by the use of $\left[{ }^{3} \mathrm{H}\right] \mathrm{NMPB}$ added to the plasma sample prior to processing. The $\left[{ }^{11} \mathrm{C}\right] \mathrm{NMPB}$ and $\left[{ }^{11} \mathrm{C}\right]$ metabolite fractions were determined in the well counter, and the recovery of $\left[{ }^{3} \mathrm{H}\right]$ NMPB from the cartridges was quantified by liquid scintillation spectrometry.

\section{Motion correction and image realignment}

Given the duration of the scanning period, the reconstructed NMPB images were realigned to correct for patient motion that may have occurred during the study. Molecular sieve beads (1-2 $\mathrm{mm}$ in diameter) were placed at various points on the subject's scalp prior to the study. Six to eight $\mu \mathrm{Ci}$ of $\left[{ }^{11} \mathrm{C}\right] \mathrm{NMPB}$ in a volume of $\sim 1 \mu \mathrm{l}$ were used to label the beads. Following reconstruction of the dynamic PET scan sequence, each bead was marked with a cursor in the 17th frame of the study and used as base orientation. The $(x, y, z)$ coordinates were then calculated based on the radioactivity 
distribution in the vicinity of the beads. An automated routine located and calculated the $(x, y, z)$ coordinates for each bead in the remaining 17 frames, which were then realigned to the orientation of the base frame. This method corrects for the three translational and three rotational degrees of freedom, and realigns image sets to within $0.5 \mathrm{~mm}$ and $1^{\circ}$, respectively.

\section{Tracer kinetic analysis of $\left[{ }^{11} \mathrm{C}\right] \mathrm{NMPB}$ transport and distribution}

The tracer kinetic analysis technique utilized for $\left[{ }^{11} \mathrm{C}\right] \mathrm{NMPB}$ is similar to that described in detail in prior studies from our group (Frey et al., 1985, 1992; Koeppe et al., 1992, 1994; Zubieta et al., 1998). The model includes a plasma compartment $\left(\mathrm{C}_{\mathrm{P}}\right)$ and a tissue compartment with three subcompartments. These represent free $\left(\mathrm{C}_{\mathrm{F}}\right)$, nonspecifically bound $\left(\mathrm{C}_{\mathrm{NS}}\right)$, and specifically bound $\left(\mathrm{C}_{\mathrm{S}}\right)$ radiotracer, with its exchange being governed by six rate constants $\left(\mathrm{K}_{1}-\mathrm{k}_{6}\right)$. Practically, this model is too complex for implementation with PET studies when only one tracer dose is administered. Two simplified configurations were utilized for the present analysis. A three-compartment, four-parameter model was applied, which included transport $\left(\mathrm{K}_{1}\right)$, the free plus nonspecific distribution volume $\left(\mathrm{DV}^{\prime}\right)$, and the receptor binding and dissociation rate constants $\left(\mathrm{k}_{3}^{\prime}\right.$ and $\left.\mathrm{k}_{4}\right)$. This configuration combines the free and nonspecific pools into a single compartment $\left(\mathrm{C}_{\mathrm{F}+\mathrm{NS}}\right)$ and assumes that the rate constants of exchange with the nonspecific pool $\left(\mathrm{k}_{5}\right.$ and $\left.\mathrm{k}_{6}\right)$ are rapid compared to blood-brain barrier and receptor binding transport rates $\left(\mathrm{K}_{1}-\mathrm{k}_{4}\right)$. The kinetic parameters are defined in the four-compartment model as follows:

$$
\begin{aligned}
K_{1} & =f E_{0}=f\left(1-e^{-P S / f}\right)\left(\mathrm{ml} \mathrm{g}^{-1} \mathrm{~min}^{-1}\right) \\
k_{2} & =K_{1} / D V_{F}\left(\mathrm{~min}^{-1}\right) \\
k_{3} & =k_{\text {on }} B_{\max }^{\prime} \\
k_{4} & =k_{\text {off }} \\
K_{d} & =k_{\text {off }} / k_{\text {on }} \\
k_{3} / k_{4} & =B_{\max }^{\prime} / K_{d}
\end{aligned}
$$

In the simplified three-compartment model, these rate constants are modified to:

$$
\begin{aligned}
k_{2}^{\prime} & =k_{2} /\left(1+k_{5} / k_{6}\right)=K_{1} / D V^{\prime}\left(\min ^{-1}\right) \\
& =K_{1} / D V_{F}\left(1+k_{5} / k_{6}\right)=K_{1} /\left(D V_{F+N S}\right) \\
k_{3}^{\prime} & =k_{3} f_{2}\left(\min ^{-1}\right) \\
& =k_{3} /\left(1+k_{5} / k_{6}\right) \\
& =k_{\mathrm{on}} B_{\max }^{\prime} /\left(1+k_{5} / k_{6}\right)
\end{aligned}
$$

where $f$ is cerebral blood flow $\left(\mathrm{ml} \mathrm{g}^{-1} \mathrm{~min}^{-1}\right), \mathrm{E}_{0}$ is the single pass extraction fraction of the ligand across the blood-brain barrier, PS is the capillary permeability surface area product $\left(\mathrm{ml} \mathrm{g}^{-1} \mathrm{~min}^{-1}\right), \mathrm{k}_{\mathrm{on}}$ is the bimolecular association rate between ligand and receptor ( $g$ $\left.\mathrm{pmol}^{-1} \mathrm{~min}^{-1}\right), \mathrm{B}_{\max }^{\prime}$ is the density of available receptors $\left(\mathrm{pmol} \mathrm{g}^{-1}\right), \mathrm{k}_{\text {off }}$ is the dissociation rate of ligand from the receptor complex $\left(\mathrm{min}^{-1}\right), \mathrm{K}_{\mathrm{d}}$ the equilibrium ligand binding constant for the receptor site, and $\mathrm{DV}^{\prime}$ is the summed distribution volume of the combined free and nonspecifically bound compartments $\left(\mathrm{ml} \mathrm{g}^{-1}\right)$. The quantity $\left(1+\mathrm{k}_{5} / \mathrm{k}_{6}\right)$ reflects then the increase in size of the receptor binding precursor compartment due to nonspecific binding. Assuming that the free tracer compartment achieves rapid equilibrium and $\left(\mathrm{K}_{1} / \mathrm{k}_{2}\right)$ approximates 1 , the value of $\mathrm{k}_{3}$ can be calculated from $\mathrm{k}_{3}^{\prime}$; $\mathrm{k}_{3}=\mathrm{k}_{3}^{\prime}\left[\left(\mathrm{K}_{1} / \mathrm{k}_{2}\right) /\left(1+\mathrm{k}_{5} / \mathrm{k}_{6}\right)\right]=\mathrm{k}_{3}^{\prime} \mathrm{DV}^{\prime}, \approx \mathrm{k}_{3} \mathrm{f} 2$. The ratio of receptor-related parameters $\mathrm{k}_{3} / \mathrm{k}_{4}=\mathrm{B}_{\max }^{\prime} / \mathrm{K}_{\mathrm{d}}$ is then proportional to receptor binding, provided that $\mathrm{K}_{\mathrm{d}}$ remains constant between regions, and has been referred to as the "binding potential" by Mintun et al. (1984).

Parameters were estimated by standard nonlinear least-squares analysis using the Marquardt algorithm (Bevington, 1969) with constraints restricting parameters to positive values. The effects of a cerebral blood volume (CBV) component in the measured PET data (tissue response) and the time offset between the plasma input function obtained from the radial artery and the brain activity time course were accounted for in the models. The time offset was calculated by fitting the time-activity curve of an entire slice at the midthalamic level to a two-compartment, two-parameter model, using only the first $20 \mathrm{~min}$ of data. In this fit, a whole-slice CBV of $0.035 \mathrm{ml} \mathrm{g}^{-1}(3.5 \%)$ was assumed. In all subsequent fits, the time offset was fixed to the estimated value. Local values of CBV were estimated in the individual regions as an additional model parameter.

A two-parameter, pixel-by-pixel weighted integral analysis (Alpert et al., 1984) was also utilized. If, in addition to rapid equilibration of free and nonspecific compartments, the binding and release of the ligand are rapid compared to the transport parameters $\mathrm{K}_{1}$ and $\mathrm{k}_{2}^{\prime}$, the model can be reduced to two compartments. In this simplified model, a single tissue compartment incorporates free, nonspecifically bound, and specifically bound tracer with a new $\mathrm{k}_{2}^{\prime \prime}$ rate constant reflecting the net back transport of tracer into the plasma compartment, which is defined as:

$$
\begin{aligned}
k_{2}^{\prime \prime} & =k_{2} /\left(1+k_{5} / k_{6}+k_{3} / k_{4}\right)\left(\min ^{-1}\right) \\
& =K_{1} /\left(D V_{F}+D V_{N S}+D V_{S}\right)=K_{1} / D V^{\prime \prime}
\end{aligned}
$$

and thus

$$
\begin{array}{r}
D V^{\prime \prime}=K_{1} / k_{2}\left(1+k_{5} / k_{6}+k_{3} / k_{4}\right) \\
=D V_{F+N S}+D V_{F} B_{\max }^{\prime} / K_{d}
\end{array}
$$

where $\mathrm{DV}^{\prime \prime}$ is the apparent distribution volume of the summed tissue compartments $\left(\mathrm{K}_{1} / \mathrm{k}_{2}^{\prime \prime}\right)$. In this model, 
TABLE I. Spearman's rank correlations between age and regional $\left[{ }^{11} C\right] N M P B$ transport rates $\left(K_{1}\right)$ and receptor binding parameters $\left(D V^{\prime \prime}\right.$ and $k_{3} / k_{4}$ )

\begin{tabular}{|c|c|c|c|c|}
\hline \multirow[b]{2}{*}{ Region } & \multicolumn{2}{|c|}{$\begin{array}{l}\text { Pixel-by-pixel two-compartment } \\
\text { model }\end{array}$} & \multicolumn{2}{|c|}{ Three-compartment model } \\
\hline & $K_{1}(P$ value $)$ & $D V^{\prime \prime}(P$ value $)$ & $K_{1}(P$ value $)$ & $k_{3} / k_{4}(P$ value $)$ \\
\hline Frontal cortex & $-0.42(0.09)$ & $-0.55(0.02)^{*}$ & $-0.16(0.5)$ & $-0.62(0.01)^{*}$ \\
\hline Occipital cortex & $-0.03(0.9)$ & $-0.51(0.04)^{*}$ & $-0.42(0.09)$ & $-0.54(0.03)^{*}$ \\
\hline Putamen & $-0.28(0.2)$ & $-0.37(0.13)$ & $0.16(0.5)$ & $-0.37(0.2)$ \\
\hline Thalamus & $-0.19(0.2)$ & $-0.53(0.03)^{*}$ & $-0.13(0.6)$ & $-0.58(0.02)^{*}$ \\
\hline Pons & $0.21(0.4)$ & $-0.54(0.03)^{*}$ & $0.20(0.4)$ & $-0.26(0.3)$ \\
\hline Cerebellum & $0.11(0.6)$ & $-0.13(0.6)$ & $0.16(0.5)$ & $0.11(0.7)$ \\
\hline Whole brain & $-0.41(0.08)$ & $-0.55(0.02)^{*}$ & - & - \\
\hline
\end{tabular}

Spearman's rank correlation coefficients and significance levels (in parentheses) between age and $\left[{ }^{11} \mathrm{C}\right] \mathrm{NMPB}$ transport and binding parameters in 18 healthy subjects. In the first two columns the values express the correlation coefficients for the transport rate $\left(K_{1}\right)$ and binding parameter $\left(D V^{\prime \prime}\right)$ obtained from a two-compartment model with a pixel-by-pixel implementation. The last two columns show the values corresponding to regional three-compartment fits, in which the binding parameter is defined as the ratio $k_{3} / k_{4}$.

* Statistically significant at a level of $P<0.05$

receptor information is represented only by $\mathrm{DV}^{\prime \prime}$. As the ratio of association to dissociation rate $\left(\mathrm{k}_{3} / \mathrm{k}_{4}\right)$ becomes progressively higher, the specific distribution volume term dominates, and $\mathrm{DV}^{\prime \prime}$ yields a progressively better estimate of $\mathrm{B}_{\mathrm{max}}^{\prime} / \mathrm{K}_{\mathrm{d}}$. This approach yields parametric images of ligand delivery $\left(\mathrm{K}_{1}\right)$ and receptor binding $\left(\mathrm{DV}^{\prime \prime}\right)$. In this case, the first $30 \mathrm{sec}$ of scan data were omitted from the calculations to reduce CBV effects on the estimated parameters (Koeppe et al., 1987).

\section{Data analysis}

For examination of the effects of aging on the regional patterns of $\left[{ }^{11} \mathrm{C}\right] \mathrm{NMPB}$ transport and receptor binding, irregular regions of interest (ROIs) were drawn on the $K_{1}$ images obtained from the weighted integral pixel-by-pixel analysis, following the contour of the gray matter. These ROIs were then applied to the DV" images of that subject. In the case of the $\mathrm{AD}$ patients, homologous ROIs were identified in the metabolic images obtained with $\left[{ }^{18} \mathrm{~F}\right] \mathrm{FDG}$, and were then applied to $\mathrm{K}_{1}$ and $\mathrm{DV}^{\prime \prime}$ pixel-by-pixel maps. This allowed for a more accurate delimitation of the cortical regions (parietal cortex) that showed abnormal metabolic patterns in the FDG images.

Statistical comparisons between controls and $\mathrm{AD}$ patients or between groups within the healthy subjects were performed via ANOVA for multiple comparisons (regions). When the ANOVA detected a significant interaction, regional differences between groups were then evaluated with post-hoc Dunnett's $t$-tests, with a minimum level of significance of $P<0.05$. Associations between age and radioligand transport or ligand binding values were tested with nonparametric Spearman's rank correlations, with a minimum level of significance of $P<0.05$. Values are expressed as the mean \pm 1 SD.

\section{RESULTS \\ Age-dependency of $\left[{ }^{11} \mathrm{C}\right]$ NMPB transport and binding parameters}

The association between regional and whole brain $\mathrm{K}_{1}$ and binding potential values with age is shown in
Table I. No significant correlations were observed between tracer transport and age for any of the brain regions considered. Conversely, binding estimates obtained with either a pixel-by-pixel or a three-compartment model showed significant reductions with advancing age in neocortical regions (frontal and occipital cortex) and thalamus (Table I, Fig. 1). Whole brain values obtained with the pixel-by-pixel two-compartment model were also significantly decreased with age. Pons reached statistically significant correlations only in the simpler model configuration, but not in the threecompartment model. No significant correlations with age were obtained for putamen and cerebellum with either of the two models (Spearman's rank correlation, $P>0.05$ ).

When the binding values obtained in the youngest cohort studied (second decade of age, $23 \pm 2, \mathrm{n}=10$ ) were compared with those in older subjects (age $>55$, mean $69 \pm 11$ years old, $\mathrm{n}=6$ ), ANOVA with repeated measures identified an age-group by region interaction $(P<0.01)$ for both DV" (two-compartment model) and $\mathrm{k}_{3} / \mathrm{k}_{4}$ (three-compartment) values. For DV" post-hoc Dunnett's $t$-tests showed significant reductions $(P<$ 0.05 ) in frontal cortex (mean change 26\%), occipital cortex (mean change $30 \%$ ), thalamus (26\%), and whole brain (23\%), but no significant differences in putamen (12\%), pons (22\%), and cerebellum (no changes noted). Similarly to the above results, when the $\mathrm{k}_{3} / \mathrm{k}_{4}$ values obtained with the three-compartment model were compared between the younger and older cohorts, significant differences were obtained in frontal cortex, occipital cortex, and thalamus, with mean reductions in binding values of $35 \%, 34 \%$, and $32 \%$, respectively. Again, no significant differences were reached in putamen (mean change $17 \%$ ), pons (18\%), or cerebellum (no change).

\section{Muscarinic receptor binding in Alzheimer disease Pixel-by-pixel two-compartment tracer kinetic model}

In Table II we show the regional distribution of tracer transport $\left(\mathrm{K}_{1}\right)$ and receptor binding $\left(\mathrm{DV}^{\prime \prime}\right)$ val- 
Three Compartment Model

FRONTAL CORTEX

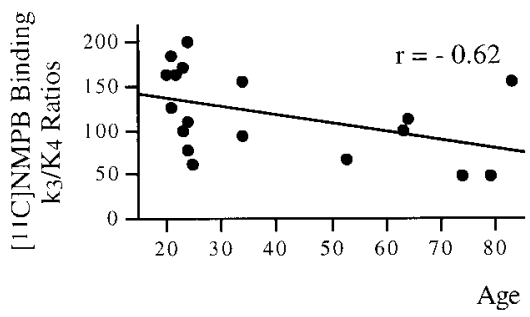

THALAMUS

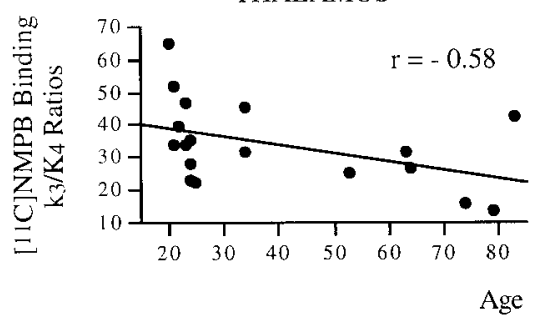

CEREBELLUM

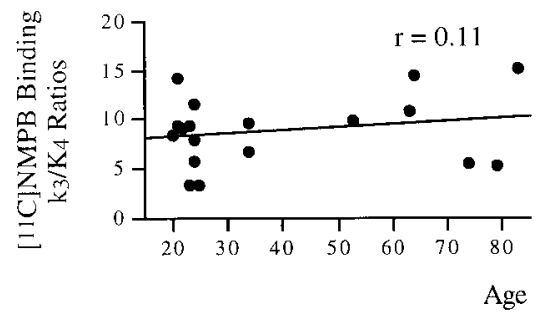

Two Compartment Model

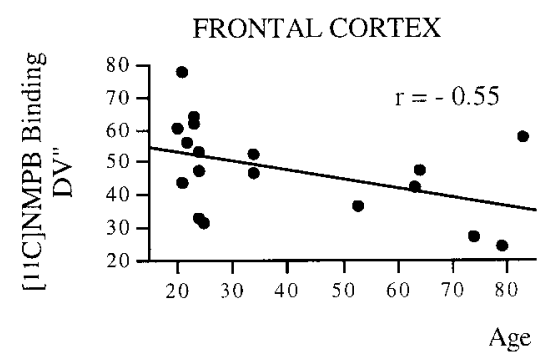

THALAMUS

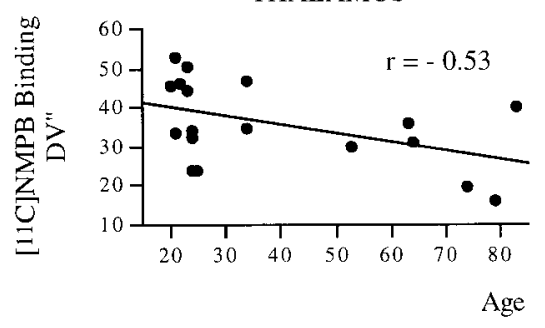

CEREBELlum

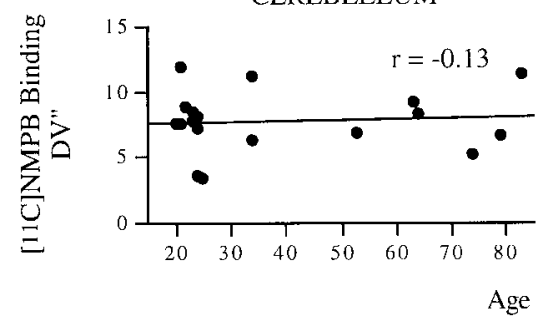

Fig. 1. Correlations between age and regional receptor density estimations obtained with a pixel-by-pixel implementation of a two-compartment model and a three-compartment model. Data presented correspond to three representative regions, two of which showed negative correlations with age and one (cerebellum) in which no association between age and receptor concentrations were noted.

TABLE II. [ ${ }^{11}$ C]NMPB kinetic parameter estimates, two-compartment weighted integral pixel-by-pixel fits; Alzheimer disease, age-matched elderly controls, and young controls

\begin{tabular}{|c|c|c|c|c|c|c|}
\hline \multirow[b]{2}{*}{ Regions } & \multicolumn{3}{|c|}{$K_{1}$} & \multicolumn{3}{|c|}{$D V^{\prime \prime}$} \\
\hline & $\mathrm{AD}$ & ECtr & YCtr & $\mathrm{AD}$ & ECtr & YCtr \\
\hline Frontal cortex & $0.24(0.04)^{*}$ & $0.32(0.03)$ & $0.31(0.05)$ & $32(11)$ & 39 (13) & $42(9)$ \\
\hline Parietal cortex & $0.20(0.06)^{*}$ & $0.31(0.03)$ & $0.29(0.05)$ & $21(6)^{*}$ & $38(13)$ & $40(10)$ \\
\hline Occipital cortex & $0.32(0.08)^{*}$ & $0.36(0.02)$ & $0.33(0.06)$ & $34(5)$ & $39(13)$ & $46(11)$ \\
\hline Putamen & $0.30(0.04)$ & $0.39(0.05)$ & $0.35(0.04)$ & $37(11)$ & $53(17)$ & $48(13)$ \\
\hline Thalamus & $0.28(0.04)^{*}$ & $0.36(0.02)$ & $0.32(0.05)$ & $22(6)$ & $29(9)$ & $32(9)$ \\
\hline Pons & $0.24(0.02)^{*}$ & $0.33(0.07)$ & $0.25(0.04)$ & $17(3)$ & $20(6)$ & $22(7)$ \\
\hline Cerebellum & $0.28(0.02)$ & $0.35(0.09)$ & $0.30(0.04)$ & $7(2)$ & $8(2)$ & $7(3)$ \\
\hline Whole brain & $0.19(0.03) *$ & $0.26(0.02)$ & $0.25(0.04)$ & $23(6)$ & $29(9)$ & $32(7)$ \\
\hline \multicolumn{7}{|c|}{ Region/Thalamus Ratios } \\
\hline Frontal cortex & $0.85(0.15)$ & $0.89(0.09)$ & $0.99(0.08)$ & $1.42(0.21)$ & $1.37(0.15)$ & $1.32(0.12)$ \\
\hline Parietal cortex & $0.71(0.17)^{*}$ & $0.85(0.08)$ & $0.91(0.05)$ & $0.99(0.14)^{*}$ & $1.32(0.16)$ & $1.23(0.13)$ \\
\hline Occipital cortex & $1.16(0.22)$ & $1.00(0.05)$ & $1.05(0.07)$ & $1.63(0.30)$ & $1.38(0.19)$ & $1.43(0.12)$ \\
\hline Putamen & $1.07(0.15)$ & $1.06(0.12)$ & $1.12(0.11)$ & $1.70(0.22)$ & $1.87(0.16)^{* * *}$ & $1.49(0.23)$ \\
\hline Pons & $0.86(0.12)$ & $0.90(0.19)$ & $0.80(0.09)$ & $0.77(0.10)$ & $0.72(0.13)$ & $0.67(0.12)$ \\
\hline Cerebellum & $1.01(0.19)$ & $0.96(0.24)$ & $0.96(0.15)$ & $0.31(0.03)$ & $0.29(0.07)^{* *}$ & $0.20(0.04)$ \\
\hline Whole brain & $0.67(0.07)$ & $0.70(0.06)$ & $0.78(0.02)$ & $1.03(0.08)$ & $1.04(0.10)$ & $1.01(0.09)$ \\
\hline
\end{tabular}

Transport rate constants $\left(K_{1}\right)$ and distribution volume $\left(D V^{\prime \prime}\right)$ of $\left[{ }^{11} \mathrm{C}\right] \mathrm{NMPB}$ in patients diagnosed with Alzheimer disease (AD), age-matched elderly controls $(\mathrm{ECtr})$, and a young control reference group (YCtr), calculated from a two-compartment model, implemented in a pixel-by-pixel basis (standard deviation of the mean in parentheses). Statistical comparisons were performed between AD and ECtr, and between ECtr and YCtr groups.

*Significantly different from elderly age-matched controls, ANOVA with post-hoc Dunnett $t$-tests, $P<0.05$.

**Comparison between elderly controls and young controls, significant at level $P<0.05$ (ANOVA with Dunnett $t$-test). 
ues, using a pixel-by-pixel, two-parameter, two-compartment model analysis, in six subjects diagnosed with $\mathrm{AD}$. As a comparison group, we show results for six age-matched elderly controls. An additional reference group consisting of six young healthy subjects $(27 \pm 5$ years old) was also included in the table to facilitate comparisons across age groups. Statistical comparisons were performed between $\mathrm{AD}$ and agematched elderly controls, and between elderly and young control groups.

Regional and whole brain $\mathrm{K}_{1}$ values were generally lower in the patient group, compared with age-matched controls, with the exception of putamen and cerebellum, which did not show significant differences. Mean reductions in $\mathrm{K}_{1}$ ranged from $35 \%$ (parietal cortex) to $20 \%$ (putamen, cerebellum).

Regional $\mathrm{K}_{1}$ values were also normalized to those of the thalamus, selected as an area that does not show clear changes in cerebral blood flow or metabolism in $\mathrm{AD}$ (see Discussion). After normalization, the ratios $\mathrm{ROI} /$ thalamus were not different between $\mathrm{AD}$ patients and elderly controls, or between elderly controls and young controls. The only exception was the parietal cortex, in which statistically significant reductions in $\mathrm{K}_{1}$ rates in $\mathrm{AD}$ were still apparent. Ratio values in the occipital cortex were slightly higher in $\mathrm{AD}$ than in the control groups; although the differences did not reach statistical significance, they probably reflect relatively preserved $\mathrm{rCBF}$ and tracer transport in this region. No significant differences in $\mathrm{K}_{1}$ were observed between elderly and young controls groups for absolute or normalized values (ANOVA $P>0.05$ ).

The receptor-related parameter $\mathrm{DV}^{\prime \prime}$ was also generally lower in $\mathrm{AD}$ subjects than in age-matched controls for most regions and whole brain, although the only area in which these differences reached statistical significance was the parietal cortex (mean difference $43 \%$ ). Other regions showed mean reductions of $19 \%$ (frontal cortex), 12\% (occipital cortex), 30\% (putamen), $24 \%$ (thalamus), 18\% (pons), and 16\% (cerebellum). After normalization to thalamic DV" values, the moderate, statistically nonsignificant reductions in regional $\mathrm{DV}^{\prime \prime}$ values were abolished except in the parietal cortex, in which the parietal/thalamus ratio showed a mean reduction of $25 \%$ (Fig. 2). This area coincided with the region showing the largest reductions in rCMRglu (Fig. 2, top row).

\section{Regional three-compartment model}

In Table III we present results obtained with the three-compartment model configuration. Transport rates $\left(\mathrm{K}_{1}\right)$ were again observed to be significantly decreased in frontal and parietal cortices, thalamus, pons, and cerebellum of $\mathrm{AD}$ subjects, compared with age-matched controls, but not in the occipital cortex or putamen. Focal reductions in $\mathrm{K}_{1}$ after normalization to thalamic $\mathrm{K}_{1}$ values were apparent only in the parietal cortex (mean change 20\%).

The combined free and nonspecific volumes of distribution $\left(\mathrm{DV}^{\prime}\right)$ were similar across the brain regions analyzed and between subject groups (ANOVA $P>0.05$, data not shown). With the more complex configuration, the individual values of $\mathrm{k}_{3}$ and $\mathrm{k}_{4}$ suffered from high statistical uncertainty (\% coefficients of variation ranging from $30-80 \%)(\%$ coefficient of variation, $\% \mathrm{COV}=$ (standard deviation $\div$ mean) $\times 100$ ). Therefore, the binding potential $\left(\mathrm{k}_{3} / \mathrm{k}_{4}\right)$ was used to provide a stable index of binding density for this model configuration.

Mean regional $k_{3} / k_{4}$ ratios were generally lower in $\mathrm{AD}$ patients than in elderly controls, with average reductions ranging from 5\% in occipital cortex to $30 \%$ in parietal cortex, and intermediate values for the remaining regions. None of the regional values reached statistically significant differences between $\mathrm{AD}$ and age-matched controls.

Regional binding potential values were then normalized to the thalamic values of each subject. Normalization to a reference region would presumably eliminate possible global differences in binding values that may be present in $\mathrm{AD}$, as well as intersubject variability secondary to experimental factors. After normalization, mean $\mathrm{k}_{3} / \mathrm{k}_{4}$ values were nearly identical between $\mathrm{AD}$ patients, elderly controls, and young controls (Table III). The only exception was an increase in normalized binding potential at the level of the cerebellum from the young control to the elderly control group $(P<$ $0.05)$, probably due to regional differences in age-related changes in muscarinic receptor concentrations in these areas.

\section{DISCUSSION}

The present study was designed to examine the feasibility of using $\left[{ }^{11} \mathrm{C}\right] \mathrm{NMPB}$ for the quantification of muscarinic receptor concentrations in aging and neurodegenerative processes. We demonstrate age-related reductions in muscarinic receptor binding measures, but no evidence of regional changes in $\mathrm{AD}$, which are largely in agreement with postmortem data. A global reduction in muscarinic binding in $\mathrm{AD}$ could not be ruled out in this study, due to the variability inherent to the utilization of a three-compartment kinetic model to isolate blood flow from receptor changes.

We were primarily concerned with the unbiased estimation of two parameters, 1) transport of radiotracer from plasma to brain compartment, $\mathrm{K}_{1}$, which is a function of $\mathrm{rCBF}$ (tracer transport $=$ flow $\times$ extraction), and 2) receptor binding. Prior results from our laboratory using $\left[{ }^{11} \mathrm{C}\right] \mathrm{NMPB}$ as a tracer indicated that a pixel-by-pixel implementation of a two-compartment tracer kinetic model was not completely able to isolate changes in receptor density when tracer transport was altered experimentally (Zubieta et al., 1998). This situation is likely to be encountered in the context of $\mathrm{AD}$, 


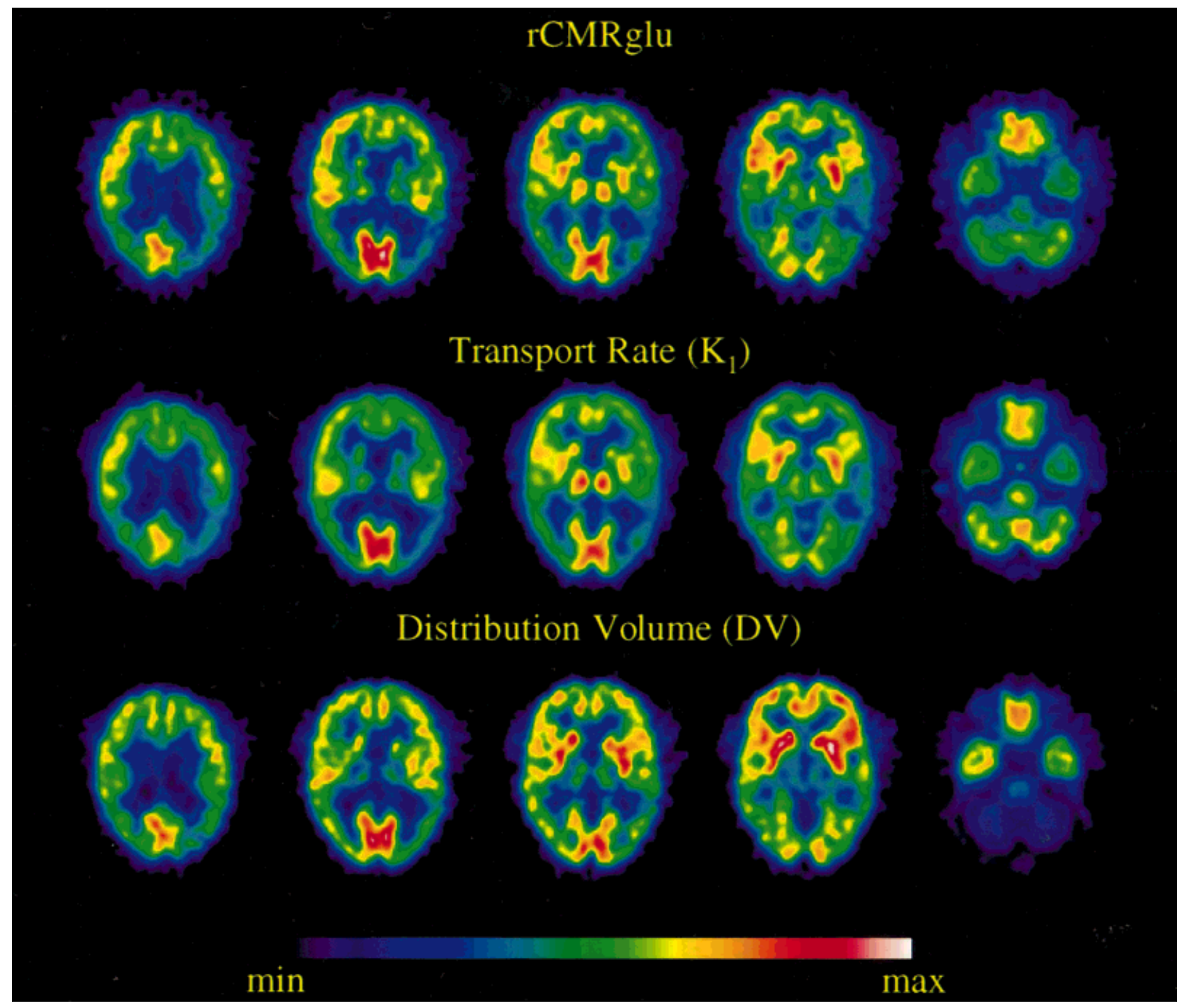

Fig. 2. Pixel-by-pixel maps of regional cerebral metabolism $\left(\left[{ }^{18} \mathrm{~F}\right]-\right.$ FDG), transport rates $\left(\mathrm{K}_{1}\right)$, and receptor distribution volume (DV) in a patient with probable AD. Marked reductions in glucose metabolism and $K_{1}$ are observed in parietal cortices, reflecting decreased function and regional cerebral blood flow, respectively. While changes in the receptor measure DV, obtained by a pixel-by-pixel implementation of a two-compartment model, are not so pronounced, a change in this region is still apparent. Receptor binding measures unbiased by the effects of tracer delivery necessitated description by a more complex three-compartment tracer kinetic model. in which reductions of both regional cerebral blood flow and metabolism have been clearly documented in associative cortical regions (Frackowiak et al., 1981; Benson et al., 1983; Foster et al., 1984; Friedland et al., 1985; Haxby et al., 1990; Jagust et al., 1990; Johnson et al., 1990). Using computer simulations based on average rate constants, pooled from 12 young healthy subjects, we also showed that the use of the cerebellar $\left[{ }^{11} \mathrm{C}\right] \mathrm{NMPB}$ concentrations as an estimate of input function were inaccurate, on the bases of significant cerebellar specific binding and regional differences in free tracer concentration (Zubieta et al., 1998). Therefore, a three-compartment tracer kinetic model, which was shown to accurately isolate tracer transport from binding processes, was also applied in the analyses of the present data.

Tracer transport was not found to be significantly altered with advancing age. A trend towards a negative correlation with age was noted in the frontal cortex with the pixel-by-pixel model, which was not confirmed in the three-compartment analysis. Global CBF does not appear to be clearly altered with age (Itoh et al., 1990; Martin et al., 1991), but mild reductions have been shown in areas of the frontal, temporal, and parietal cortices (Pantano et al., 1984; Martin et al., 1991). While $K_{1}$ values are proportional to $\mathrm{CBF}$, the lesser extraction of $\left[{ }^{11} \mathrm{C}\right] \mathrm{NMPB}$ than that of tracers developed for the measurement of $\mathrm{CBF}$, and the use of 
TABLE III. $\left[{ }^{11} C\right] N M P B$ kinetic parameter estimates, three-compartment model fits. Alzheimer disease, age-matched controls, and young controls

\begin{tabular}{|c|c|c|c|c|c|c|}
\hline \multirow[b]{2}{*}{ Regions } & \multicolumn{3}{|c|}{$K_{1}$} & \multicolumn{3}{|c|}{$k_{3} / k_{4}$} \\
\hline & $\mathrm{AD}$ & ECtr & YCtr & $\mathrm{AD}$ & ECtr & YCtr \\
\hline Frontal cortex & $0.27(0.04)^{*}$ & $0.39(0.04)$ & $0.35(0.07)$ & 31 (19) & $44(21)$ & $53(18)$ \\
\hline Parietal cortex & $0.19(0.03)^{*}$ & $0.34(0.04)$ & $0.33(0.05)$ & $33(12)$ & $47(27)$ & $50(15)$ \\
\hline Occipital cortex & $0.35(0.06)$ & $0.40(0.02)$ & $0.37(0.04)$ & $47(15)$ & $57(14)$ & $49(21)$ \\
\hline Putamen & $0.36(0.03)$ & $0.45(0.05)$ & $0.38(0.07)$ & $58(28)$ & $71(48)$ & $82(27)$ \\
\hline Thalamus & $0.34(0.09)^{*}$ & $0.48(0.04)$ & $0.41(0.09)$ & $20(4)$ & $26(11)$ & $31(9)$ \\
\hline Pons & $0.33(0.03)^{*}$ & $0.44(0.08)$ & $0.37(0.09)$ & $16(5)$ & $18(9)$ & $23(8)$ \\
\hline Cerebellum & $0.34(0.04)^{*}$ & $0.42(0.05)$ & $0.37(0.05)$ & $2(1)$ & $3(1)$ & $2(1)$ \\
\hline \multicolumn{7}{|c|}{ Region/Thalamus Ratios } \\
\hline Frontal cortex & $0.9(0.3)$ & $0.8(0.1)$ & $1.7(0.3)$ & $1.6(0.8)$ & $1.7(0.3)$ & $1.7(0.2)$ \\
\hline Parietal cortex & $0.6(0.1)^{*}$ & $0.7(0.1)$ & $1.6(0.2)$ & $1.6(0.4)$ & $1.8(0.4)$ & $1.6(0.2)$ \\
\hline Occipital cortex & $1.1(0.6)$ & $0.8(0.1)$ & $0.9(0.2)$ & $2.3(0.5)$ & $1.9(0.4)$ & $1.9(0.5)$ \\
\hline Putamen & $1.2(0.5)$ & $0.9(0.1)$ & $1.9(0.3)$ & $2.7(1.1)$ & $2.5(0.6)$ & $2.7(0.6)$ \\
\hline Pons & $1.1(0.5)$ & $0.9(0.1)$ & $0.9(0.1)$ & $0.8(0.2)$ & $0.7(0.1)$ & $0.8(0.2)$ \\
\hline Cerebellum & $1.1(0.5)$ & $0.9(0.1)$ & $1.9(0.3)$ & $0.1(0.05)$ & $0.1(0.04)$ & $0.07(0.03)^{*}$ \\
\hline
\end{tabular}

Transport rate constants $\left(K_{1}\right)$ and binding potential $\left(k_{3} / k_{4}\right)$ of $\left[{ }^{11} \mathrm{C}\right] \mathrm{NMPB}$ in patients diagnosed with Alzheimer disease (AD), age-matched elderly controls (ECtr), and a young reference group (YCtr), calculated from a three-compartment tracer kinetic model (standard deviation of the mean in parentheses). Statistical comparisons were performed between $\mathrm{AD}$ and ECtr, and between ECtr and YCtr groups.

*Significantly different from elderly control group, ANOVA with post-hoc Dunnett $t$-tests, $P<0.05$.

relatively large regions of interest in the present study, would not allow for the detection of small regional differences in plasma to brain transport rates.

Muscarinic receptor binding parameters estimated either with a two- or a three-compartment model (DV" and $\mathrm{k}_{3} / \mathrm{k}_{4}$, respectively) showed significant reductions with age in neocortical regions (frontal and occipital cortices) and in thalamus, but not in putamen or cerebellum. These results are in general agreement with those reported by Dewey et al. (1990) and Suhara et al. (1993), although the degree of reduction we observe is not as pronounced as that reported by these groups. They observed similar or larger reductions in cortical regions, and much larger age-related declines in the striatum (caudate-putamen); thalamic changes were reported only by Dewey et al. (1990). Differences between the present report and those studies may be accounted for by the different methods used for quantification of receptor densities and the radioligands utilized. In the case of $\left[\mathrm{N}^{11} \mathrm{C}\right.$-methyl]-benztropine (Dewey et al., 1990), this agent appears to display a slow ligand-receptor dissociation rate, which produces uncertainties in the estimation of specifically bound tracer volume of distribution that may impact on the precision of the measurements. In the report by Suhara et al. (1993) $\left[{ }^{11} \mathrm{C}\right] \mathrm{NMPB}$ ligand-receptor binding was calculated from a graphical method (Wong et al., 1986), 60 min of dynamic scanning, and utilizing the cerebellum as input function. This differs from the present report, in which a nongraphical kinetic analysis, actual arterial blood sampling with correction for the presence of metabolites, and a longer scanning period were utilized. Given the kinetics of $\left[{ }^{11} \mathrm{C}\right] \mathrm{NMPB}$, which in areas of high levels of specific binding (i.e., basal ganglia) reaches equilibrium only at late times of the scanning interval (Koeppe et al., 1992), shorter observation pe- riods may lead to underestimations of ligand binding in high receptor density regions. The measurements then become susceptible to even small changes in delivery in these areas (flow limited condition), with possible overestimations in age-related reductions in receptor binding. An additional factor that may have contributed to the larger changes in muscarinic receptor binding with are observed by Suhara et al. (1993), is that the cerebellum was utilized as a reference region for the calculation of binding potentials. This assumes that cerebellar muscarinic binding is negligible, that the total activity in the cerebellum reflects the input of radiotracer to the specifically bound compartment, and is that not altered with advancing age. This may not be the case, in view of the results reported by Lee et al. (1996), in which higher cerebellar binding was observed to increase with advancing age. In the present report, we also observe a significant increase in muscarinic receptor binding with age in this region. The use of this region as a reference would artifactually enhance any reductions that may be present in other areas.

The age-related reductions in muscarinic receptor densities showed contrast with prior reports in living human subjects using PET, both in the degree of change and in number of regions showing statistically significant differences between younger and older cohorts. Conversely, they are similar to results obtained with in vitro techniques using human postmortem material (Perry, 1980) or animal models (Biegon et al., 1988; Araujo et al., 1990). Alterations in muscarinic receptor densities with advancing age may be at least partially responsible for the increased sensitivity to anticholinergic agents observed in older subjects (Molchan et al., 1992). 
In contrast to the results observed in normal aging, patients diagnosed with $\mathrm{AD}$ demonstrate significant reductions in tracer transport in most of the brain regions studied. Largest reductions were noted in the parietal cortex, followed in severity by frontal cortex, thalamus, and pons, while occipital cortex, putamen, and cerebellum differences did not reach statistical significance. The parietal cortex was known to be most affected metabolically because of the inclusion criteria in the study (biparietal hypometabolism), and it was expected that this area would display the more severe reductions in regional $\mathrm{CBF}$ as well, impacting directly on tracer transport rates.

In the context of limitations in tracer delivery, it was of interest to compare the performance of a simpler tracer kinetic approach (pixel-by-pixel implementation of a two-compartment model, which yields parametric images of $\mathrm{K}_{1}$ and $\mathrm{DV}^{\prime \prime}$ ), with a more complex, hence potentially less precise, but less biased regional threecompartment tracer kinetic model. In the pixel-by-pixel approach, significant reductions in the binding-related parameter DV" were identified in the parietal cortex of patients diagnosed with $\mathrm{AD}$ compared with agematched controls. This finding was still apparent after normalization to thalamic DV" values. The thalamus was selected as a reference area on the bases of prior reports documenting the relative preservation of its metabolic, regional CBF, and presumably neural function in AD (Frackowiak et al., 1981; Benson et al., 1983; Foster et al., 1984; Friedland et al., 1985; Kantzman, 1986). Normalization to thalamic ligand binding values served two purposes. It would differentiate individual reductions secondary to aging from those due to the illness, since the thalamus was one of the areas in which age had a clear effect on muscarinic receptor densities, but was less likely to be affected in $\mathrm{AD}$. It also helped reduce uncertainties that may be associated to interexperimental variability. This is of specific interest in the interpretation of data derived from the three-compartment tracer kinetic model, in which the variance was increased by a larger number of unknowns (calculation of four rate constants, instead of the two parameters estimated in the simpler model). However, the use of a reference region assumes that no changes in this area are present in the disease process to be studied. While this may be the case in $\mathrm{AD}$, normal aging was associated with reductions in muscarinic binding in the thalamus. This may introduce errors in the comparison of regional binding between young and older populations. This was observed in our data as increases in the normalized cerebellar values in older controls compared to young controls. Since the cerebellum did not show changes with advancing age, normalization to thalamus was likely to have introduced artifactual errors in this situation.

Using a three-compartment model configuration, mean regional values of binding potential $\left(\mathrm{k}_{3} / \mathrm{k}_{4}\right)$ were generally lower in $\mathrm{AD}$ patients than in age-matched controls, although those differences did not reach statistical significance for any of the regions analyzed. This may reflect moderate global reductions in total muscarinic receptor densities in $\mathrm{AD}$, statistically undetected because of the small sample and larger variance of this model. After normalization to the individual thalamic values the variability in the data was reduced, these changes were no longer apparent, and the mean of the $\mathrm{k}_{3} / \mathrm{k}_{4}$ ratios were nearly identical between patients diagnosed with $\mathrm{AD}$, age-matched elderly controls, and a young control reference group. In the present example, the percent coefficient of variation in the parietal cortex of $\mathrm{AD}$ patients was reduced from $37 \%$ to $23 \%$ after normalization. The largest variability was observed in the frontal cortex of $\mathrm{AD}$ patients $(62 \%$ $\mathrm{COV}$ in the original data and $77 \% \mathrm{COV}$ after normalization) compared to that of age-matched controls (48\% before and $17 \%$ after normalization). The source of variance in this region is unclear, although it may reflect individual differences in disease process or the existence of subtypes within the $\mathrm{AD}$ group (i.e., more pronounced degeneration of frontal cholinergic projections). Any specific conclusions regarding possible subtypes of clinically diagnosed $\mathrm{AD}$, or relationships between muscarinic receptor densities and cognitive function, are beyond the scope of the present study but may be an area of interest for future research.

The data presented do not support the presence of regional reductions in total muscarinic receptor densities in $\mathrm{AD}$. It is possible, however, that mild to moderate global changes in receptor availability may exist, as suggested by the decreased mean binding potential in all the brain regions considered. The small sample size included in the data does not allow for more precise conclusions: given the variance of the unnormalized data, approximately $50 \%$ reduction in binding potential values would be required to find a significant difference between groups with that sample size at $80 \%$ power and a one-tailed unpaired $t$-test. In addition, more pronounced gray matter atrophy in $\mathrm{AD}$ could also be responsible for some of the global reductions in the muscarinic receptor measurements obtained with PET.

Our results are in clear contrast with those reported by other groups (Holman et al., 1985; Weinberger et al., 1991, 1992; Ichimiya et al., 1995). In the two former series, the distribution of $\left[{ }^{123} \mathrm{I}\right] \mathrm{QNB}$ was found to be decreased in cortical association areas of patients with $\mathrm{AD}$. In the initial report by Holman et al., the reduction in regional QNB uptake was of lesser degree than that of the CBF tracer $\left[{ }^{123} \mathrm{I}\right] \mathrm{N}$-isopropyl $p$-iodoamphetamine. In subsequent descriptions (Weinberger et al., 1991, 1992), it was noted that the uptake of labeled QNB identified more abnormal regions, and was more severely reduced than the metabolic patterns obtained with $\left[{ }^{18} \mathrm{~F}\right] \mathrm{FDG}$. This led to the proposal that the distribution of the iodinated muscarinic antagonist was a 
more accurate measure of the degree of disease progression that metabolic imaging. In a later report (Ichimiya et al., 1995), reductions in parietal cortex tracer deposition were observed with $\left[{ }^{11} \mathrm{C}\right] \mathrm{NMPB}$ using a graphical analysis with cerebellum as input function. The differences encountered between the present report and prior studies are likely to be secondary to differences in radiotracer kinetics and methods of quantification employed. In this regard, estimates of the NMPB dissociation rate from receptors $\left(\mathrm{k}_{4}\right.$ values 0.06-0.10 $\mathrm{min}^{-1}$ ) (Zubieta et al., 1998) are higher than for previously used tracers. This property allows more accurate determination of ligand-receptor dissociation rates during the limited time in which scanning can be performed with ${ }^{11} \mathrm{C}$-labeled tracers. Additionally, receptor binding estimates that utilize a reference region as input function (e.g., cerebellar activity; Ichimiya et al., 1995) may suffer from significant biases. In the case of the cerebellum, not all the tracer activity present in this region represents free tracer (approximately half is bound); free tracer concentration is also regionally variable, so that its values could not be extrapolated between regions (Zubieta et al., 1998). The distribution volume of free and nonspecific tracer is approximately $\left[\left(\mathrm{K}_{1} / \mathrm{k}_{2}\right)+\mathrm{k}_{3}\right]$, and therefore it can be uniform without the actual free concentration being the same. In this manner, free tracer concentrations in cortical areas and in the basal ganglia, rich in muscarinic receptors, will be less than in an area with low muscarinic binding, such as the cerebellum.

Similar to the data presented, autopsy and biopsy studies, in which the total number of muscarinic receptors was quantified in vitro, uniformly describe a preservation of receptor densities in $\mathrm{AD}$ (Davies and Verth, 1978; Perry et al., 1978; Sakurada et al., 1990; Schroder et al., 1991; DeKosky et al., 1992). Since the nonselective markers NMPB or QNB label all muscarinic receptor subtypes, it is possible that alterations in the densities of one of the subtypes would not be detected by these radioligands. Currently, up to three subtypes have been described using functional and pharmacological characterizations (Doods et al., 1987; Hulme et al., 1990; Zubieta and Frey, 1993), and five have been defined by molecular biologic techniques (Buckley et al., 1988; Dorje et al., 1991; Levey et al., 1991). Additionally, it has been suggested that both presynaptic degeneration and upregulatory processes may coexist in $\mathrm{AD}$ (Harrison et al., 1991; Aubert et al., 1992), further complicating the interpretation of data.

The work presented here points towards some possible future research directions. Primarily, that it is necessary to develop radiotracers with more favorable kinetic properties and subtype selectivity for the study of muscarinic receptors in neurogenerative processes. Selective reductions in the $\mathrm{M}_{2}$ subtype have been reported in vitro in cortical regions in some postmortem studies of AD (Mash et al., 1985; Araujo et al., 1988;
Quirion et al., 1989; Rinne et al., 1989; Aubert et al., 1992). In vivo human imaging with SPECT and (-)-5$\left[{ }^{123} \mathrm{I}\right]$ iodobenzovesamicol, a presynaptic marker of vesicular uptake sites, has shown reductions in patients with $\mathrm{AD}$ in cortical and, to a lesser extent, in basal ganglia regions, and suggested regionally specific patterns of neuronal degeneration in early- and late-onset illness (Kuhl et al., 1996). Further development in this area is of special importance with the appearance of pharmacological treatments for $\mathrm{AD}$. Monitoring of treatment responses and investigation of the actions of novel drugs could be accomplished noninvasively with these techniques. Further subtyping of $\mathrm{AD}$ at early stages of the disease, when treatment intervention could be successful when better targeted to specific patterns of degeneration, would also be of interest in this field.

\section{REFERENCES}

Alpert NM, Eriksson L, Chang JY, Bergstrom M, Litton JE, Correia JA, Bohm C, Ackerman RH, Taveras JM. 1984. Strategy for the measurement of regional cerebral blood flow using short-lived tracers and emission tomography. J Cereb Blood Flow Metab 4:28-34.

APA (American Psychiatric Association). 1987. Diagnostic and statistical manual of mental disorders, 3rd ed, revised. Washington DC: American Psychiatric Association.

Araujo DM, Lapchak PA, Robitaille Y, Gauthier S, Quirion R. 1988. Differential alteration of various cholinergic markers in cortical and subcortical regions of human brain in Alzheimer's disease. J Neurochem 50:1914-1923.

Araujo DM, Lapchak PA, Meaney MJ, Collier B, Quirion R. 1990. Effects of aging on nicotinic and muscarinic autoreceptor function in the rat brain: relationship to presynaptic cholinergic markers and binding sites. J Neurosci 10:3069-3078.

Aubert I, Araujo DM, Cecyre D, Robitaille Y, Gauthier S, Quirion R. 1992. Comparative binding densities of nicotinic and muscarinic binding sites in Alzheimer's and Parkinson's diseases. J Neurochem 58:529-541.

Benson DF, Kuhl DE, Hawkins RA, Phelps ME, Cummings JL, Tsai SY. 1983. The fluorodeoxyglucose ${ }^{18} \mathrm{~F}$ scan in Alzheimer's disease and multi-infarct dementia. Arch Neurol 40:711-714.

Bevington PR. 1969. Data reduction and error analysis for the physical sciences. New York: McGraw-Hill. p 232-241.

Biegon A, Duvdevani R, Greenberg V, Segal M. 1988. Aging and brain cholinergic muscarinic receptors: an autoradiographic study in the rat. J Neurochem 51:1381-1385.

Bonte FJ, Tintner R, Weiner MF, Bigio EH, White CL. 1993. Brain blood flow in the dementias: SPECT and histopathologic correlation. Radiology 186:361-365.

Bowen DM, Benton JS, Spillane JA, Smith CCT, Allen SJ. 1982. Choline acetyltransferase activity and histopathology of frontal neocortex from biopsies of demented patients. J Neurol Sci 57:191202.

Brady DR, Mufson EJ. 1990. Amygdaloid pathology in Alzheimer's disease: qualitative and quantitative analysis. Dementia 1:5-17.

Buckley NJ, Bonner TI, Brann MR. 1988. Localization of a family of muscarinic receptor mRNA's in rat brain. J Neurosci 8:4646-4652.

Davies P, Maloney AJF. 1976. Selective loss of central cholinergic neurons in Alzheimer's disease. Lancet 2:1403.

Davies P, Verth AH. 1978. Regional distribution of muscarinic cholinergic receptor in normal and Alzheimer's-type dementia brains. Brain Res 138:385-392.

DeKosky ST, Scheff SW. 1990. Synapse loss in frontal cortex biopsies in Alzheimer's disease. Ann Neurol 27:457-464.

DeKosky ST, Harbaugh RE, Schmitt FA, Bakay RAE, Chui HC, Knopman DS, Reeder TM, Shetter AG, Senter HJ, Markesbery WR. 1992. Cortical biopsy in Alzheimer's disease: diagnostic accuracy and neurochemical, neuropathological, and cognitive correlations. Ann Neurol 32:625-632.

Dewey SL, McGregor RR, Brodie JD, Bendreim B, King PT, Volkow ND, Schyler DJ, Fowler JS, Wolf AP, Gatley SJ, Hitzeman R. 1990a. Mapping muscarinic receptors in human and baboon brain using $\left[\mathrm{N}-{ }^{11} \mathrm{C}-\mathrm{Methyl}\right]$ benztropine. Synapse 5:213-223. 
Dewey SL, Volkow ND, Logan J, MacGregor RR, Fowler JS, Schlyer DJ, Bendriem B. 1990b. Age-related decreases in muscarinic cholinergic receptor binding in the human brain measured with positron emission tomography, PET. J Neurosci Res 27:569-575.

Doods HN, Mathy MJ, Davidesko D, van CK, de JA, van ZP. 1987. Selectivity of muscarinic antagonists in radioligand and in vivo experiments for the putative M1, M2 and M3 receptors. J Pharmacol Exp Ther 242:257-262.

Dorje F, Wess J, Lambrecht G, Tacke R, Mutschler E, Brann MR. 1991. Antagonist binding profiles of five cloned human muscarinic receptor subtypes. J Pharmacol Exp Ther 256:727-733.

Eckelman WC, Reba RC, Rzeszotarski WJ, Gibson RE, Hill T, Holman BL, Budinger TF, Conklin JJ, Eng R, Grisom MP. 1984. External imaging of cerebral muscarinic acetylcholine receptors. Science 223: 291-293.

Foster NL, Chase TN, Mansi L, Brooks R, Fedio P, Patronas NJ, Di Chiro, G. 1984. Cortical abnormalities in Alzheimer's disease. Ann Neurol 16:649-654.

Frackowiak RSJ, Pozzilli C, Legg NJ, Du Boulay GH, Marshall J, Lenzi GL, Jones T. 1981. Regional cerebral oxygen supply and utilization in dementia; a clinical and physiological study with oxygen-15 and positron emission tomography. Brain 104:753-778.

Frey KA, Hichwa RD, Ehrenkaufer RLE, Agranoff BW. 1985. Quantitative in vivo receptor binding. III. Tracer kinetic modeling of muscarinic receptor binding. Proc Natl Acad Sci USA 82:67116715.

Frey KA, Koeppe RA, Mulholland GK, Jewett D, Hichwa R, Ehrenkaufer RLE, Carey JE, Wieland DM, Kuhl DE, Agranoff BW. 1992. In vivo muscarinic cholinergic receptor imaging in human brain with $\left[{ }^{11} \mathrm{C}\right]$ scopolamine and positron emission tomography. J Cereb Blood Flow Metab 12:147-154.

Friedland RP, Brun A, Budinger TF. 1985. Pathological and positron emission tomographic correlations in Alzheimer's disease. Lancet $1: 228-229$

Giacobini E. 1990. Cholinergic receptors in human brain: effects of aging and Alzheimer's disease. J Neurosci Res 27:548-560.

Harrison PJ, Barton AJL, Najlerahim A, McDonald B, Pearson RCA. 1991. Increased muscarinic receptor messenger RNA in Alzheimer's disease temporal cortex demonstrated by in situ hybridisation histochemistry. Mol Brain Res 9:15-21.

Haxby JV, Grady CL, Koss E, Horwitz B, Heston L, Schapiro M, Friedland RP, Rapoport SI. 1990. Longitudinal study of cerebral metabolic asymmetries and associated neuropsychological patterns in early dementia of the Alzheimer's type. Arch Neurol 47:753-760.

Holman BL, Gibson RE, Hill TC, Eckelman WC, Albert M, Reba RC. 1985. Muscarinic acetylcholine receptors in Alzheimer's disease. JAMA 254:3063-3066.

Hulme EC, Birsdall NJM, Buckley NJ. 1990. Muscarinic receptor subtypes. Annu Rev Pharmacol Toxicol 30:633-673.

Ichimiya A, Takita M, Yoshida T, Kuwabara Y, Sasaki M, Ichiya Y. 1995. Distribution of cerebral acetylcholine receptors in dementia of the Alzheimer type: a preliminary study with PET and ${ }^{11} \mathrm{C}$-labeled N-methyl-4-piperidylbenzylate. J Cereb Blood Flow Metab 15(Suppl. 1):S101.

Itoh M, Hatazawa J, Miyazawa H, Matsui H, Meguro K, Yanai K, Kubota K, Watanuki S, Ido T, Matsuzawa T. 1990. Stability of cerebral blood flow and oxygen metabolism during normal aging. Gerontology 36:43-48.

Jagust WJ, Reed BR, Seab JP, Budinger TF. 1990. Alzheimer's disease. Age at onset and single-photon emission computed tomographic patterns of regional cerebral blood flow. Arch Neurol 47: 628-633.

Johnson KA, Holman L, Rosen TJ, Nagel JS, English RJ, Growdon JH. 1990. Iofetamine I 123 single photon emission computed tomography is accurate in the diagnosis of Alzheimer's disease. Arch Intern Med 150:752-756.

Kantzman R. 1986. Alzheimer's disease. N Engl J Med 314:964-973.

Koeppe RA. 1990. Compartmental modeling alternatives for kinetic analysis of PET neurotransmitter/receptor studies. In: Kuhl DE, editor. Frontiers in nuclear medicine: in vivo imaging of neurotransmitter functions in brain, heart, and tumors. Washington DC: American College of Nuclear Physicians. p 113-139.

Koeppe RA, Hutchins GD, Rothley JM, Hichwa RD. 1987. Examination of assumptions for local cerebral blood flow studies in PET. J Nucl Med 28:1695-1703.

Koeppe RA, Frey KA, Zubieta JK, Fessler JA, Mulholland GK, Kilbourn MR, Mangner TJ, Kuhl DE. 1992. Tracer kinetic analysis of $\left.{ }^{[11} \mathrm{C}\right] \mathrm{N}$-methyl-4-piperidyl benzylate binding to muscarinic cholinergic receptors. J Nucl Med 33:882.

Koeppe RA, Frey KA, Mulholland GK, Kilbourn MR, Buck FL, Lee KS, Kuhl DE. 1994. $\left[{ }^{11} \mathrm{C}\right]$ Tropanyl benzylate binding to muscarinic cholinergic receptors; methodology and kinetic modeling alternatives. J Cereb Blood Flow Metab 14:85-99.

Kuhl DE, Minoshima S, Fessler JA, Frey KA, Foster NL, Ficaro EP, Wieland DM, Koeppe RA. 1996. In vivo mapping of cholinergic terminals in normal aging, Alzheimer's disease, and Parkinson's disease. Ann Neurol 40:399-410.

Lee KS, Frey KA, Koeppe RA, Buck A, Mulholland GK, Kuhl DE. 1996. In vivo quantification of cerebral muscarinic receptors in normal human aging using positron emission tomography and $\left.{ }^{[11} \mathrm{C}\right]$ tropanyl benzilate. J Cereb Blood Flow Metab 16:303-310.

Levey AI, Kitt CA, Simonds WF, Price DL, Brann MR. 1991. Identification and localization of muscarinic acetylcholine receptor proteins in brain with subtype-specific antibodies. J Neurosci 11:32183226.

Martin AJ, Friston KJ, Colebatch JG, Frackowiak RS. 1991. Decreases in regional cerebral blood flow with normal aging. J Cereb Blood Flow Metab 11:684-689.

Mash DC, Flynn DD, Potter LT. 1985. Loss of $\mathrm{M}_{2}$ muscarinic receptors in the cerebral cortex in Alzheimer's disease and experimental cholinergic denervation. Science 228:1115-1117.

McKhann G, Drachman D, Folstein M, Katzman R, Price D, Stadlan EM. 1984. Clinical diagnosis of Alzheimer's disease. Neurology 34:939-944.

Minoshima S, Berger KL, Lee KS, Mintun MA. 1992. An automated method for rotational correction and centering of three-dimensional functional brain images. J Nucl Med 33:1579-1585.

Mintun MA, Raichle ME, Kilbourn MR, Wooten GF, Welch MJ. 1984. A quantitative model for the in vivo assessment of drug binding sites with positron emission tomography. Ann Neurol 15:217-227.

Molchan SE, Martinez RA, Hill JL, Weingartner HJ, Thompson K, Vitiello B, Sunderland T. 1992. Increased cognitive sensitivity to scopolamine with age and a perspective on the scopolamine model. Brain Res Rev 17:215-226.

Müeller-Gärtner H-W, Wilson AA, Dannals RF, Wagner HN, Frost JJ. 1992. Imaging muscarinic cholinergic receptors in human brain in vivo with SPECT, $\left[{ }^{123} \mathrm{I}\right]-4$-iododexetimide and $\left[{ }^{123} \mathrm{I}\right]$-4-iodolevetimide. J Cereb Blood Flow Metab 12:562-570.

Mulholland GK, Jewett DW, Otto CA, Kilbourn MR, Sherman PS, Kuhl DE. 1988. Synthesis and regional brain distribution of $\left[\mathrm{C}^{-11}\right] \mathrm{N}-$-methyl-4-piperidyl benzylate. [C- $\left.{ }^{11}\right] \mathrm{NMPB}$. in the rat. J Nucl Med 29:768.

Nordberg A, Alafuzoff I, Winblad B. 1992. Nicotinic and muscarinic subtypes in the human brain: changes with aging and dementia. J Neurosci Res 31:103-111.

Pantano P, Baron J-C, Lebrun-Grandie P, Duquesnoy N, Bousser N-G, Comar D. 1984. Regional cerebral blood flow and oxygen consumption in human aging. Stroke 15:635-641.

Pearce BD, Liskowsky DR, Potter LT. 1992. Effect of chronic cholinergic denervation on the $\mathrm{m}_{1}$ muscarinic receptor mechanism. Neurobiol Aging 13:293-299.

Perry EK. 1980. The cholinergic system in old age and Alzheimer's disease. Age Ageing 9:1-8.

Perry EK, Tomlinson BE, Blessed G, Bergmann K, Gibson PH, Perry RH. 1978. Correlation of cholinergic abnormalities with senile plaques and mental test scores in senile dementia. Br Med J 2:1457-1459

Quirion R, Aubert I, Lapchak PA, Schaum RP, Teolis S, Gauthier S, Araujo DM. 1989. Muscarinic receptor subtypes in human neurodegenerative disorders: focus on Alzheimer's disease. Trends Pharmacol Sci 10:80-84.

Rinne JO, Lonnberg P, Marjamaki P, Rinne UK. 1989. Brain muscarinic receptor subtypes are differently affected in Alzheimer's disease and Parkinson's disease. Brain Res 483:402-406.

Sakurada T, Alufuzoff I, Winblad B, Nordberg A. 1990. Substance P-like immunoreactivity, choline acetyltransferase activity and cholinergic muscarinic receptors in Alzheimer's disease and multiinfarct dementia. Brain Res 521:329-332.

Sawada Y, Hiraga S, Francis B, Patlak C, Pettigrew K, Ito K, Owens E, Gibson R, Reba R, Eckelman W, Larson S, Blasberg RG. 1990. Kinetic analysis of 3-quinuclidinyl $4-\left[{ }^{125} \mathrm{I}\right]$ iodobenzilate transport and specific binding to muscarinic acetylcholine receptor in rat brain in vivo: implications for human studies. J Cereb Blood Flow Metab 10:781-807.

Schroder H, Giacobini E, Struble RG, Luiten PG, van der Zee Ea, Zilles K, Strosberg AD. 1991. Muscarinic cholinoceptive neurons in the frontal cortex in Alzheimer's disease. Brain Res Bull 27:631636.

Sims NR, Bowen DM, Allen SJ, Smith CC, Neary D, Thomas DJ, Davison AN. 1983. Presynaptic cholinergic degeneration in patients with dementia. J Neurochem 40:503-509.

Suhara T, Inoue O, Kobayashi K, Suzuki K, Tateno Y. 1993. Agerelated changes in human muscarinic acetylcholine receptors mea- 
sured by positron emission tomography. Neurosci Lett 149:225228.

Suhara T, Inoue O, Kobayashi K, Suzuki K, Tateno Y. 1994. An acute effect of triazolam on muscarinic cholinergic receptor binding in the human brain measured by positron emission tomography. Psychopharmacology 113:311-317.

Terry RD, Masliah E, Salmon DP, Butters N, DeTeresa R, Hill R, Hansen LA, Katzman R. 1991. Physical basis of cognitive alterations in Alzheimer's disease: synapse loss is the major correlate of cognitive impairment. Ann Neurol 30:572-580.

Wang SZ, Zhu SZ, Joseph JA, el-Fakahani EE. 1992. Comparison of the level of mRNA encoding $\mathrm{m} 1$ and $\mathrm{m} 2$ muscarinic receptors in brains of young and aged rats. Neurosci Lett 145:149-152.

Weinberger DR, Gibson R, Coppola R, Jones DW, Molchan S, Sunderland T, Berman KF, Reba R. 1991. The distribution of cerebral muscarinic acetylcholine receptors in vivo in patients with dementia. A controlled study with ${ }^{123} \mathrm{IQNB}$ and single photon emission computed tomography. Arch Neurol 48:169-176.

Weinberger DR, Jones D, Reba RC, Mann U, Coppola R, Gibson R, Gorey J, Braun A, Chase TN. 1992. A comparison of FDG PET and IQNB SPECT in normal subjects and in patients with dementia. J Neuropsychiatry Clin Neurosci 4:239-248.
White P, Hiley CR, Goodhardt MJ, Carrasco LH, Keet JP, Williams IE, Bowen DM. 1977. Neocortical cholinergic neurons in elderly people. Lancet 1:668-170.

Wilcock GK, Esiri MM, Bowen DM, Smith CCT. 1982. Alzheimer's disease: correlation of cortical choline acetyltransferase activity with the severity of dementia and histological abnormalities. J Neurol Sci 57:407-417.

Wong DF, Gjedde A, Wagner HN Jr. 1986. Quantification of neuroreceptors in the living human brain. I. Irreversible binding of ligands. J Cereb Blood Flow Metab 6:137-146.

Wyper DJ, Brown D, Patterson J, Owens J, Hunter R, Teasdale E, McCulloch J. 1993. Deficits in iodine-labeled 3-quinuclidinyl benzilate binding in relation to cerebral blood flow in patients with Alzheimer's disease. Eur J Nucl Med 20:379-286.

Zubieta JK, Frey KA. 1993. Autoradiographic mapping of $\mathrm{M}_{3}$ muscarinic receptors in the rat brain. J Pharmacol Exp Ther 264: $415-422$.

Zubieta JK, Frey KA, Koeppe RA, Kuhl DE. 1998. Quantification of muscarinic cholinergic receptors with $\left[{ }^{11} \mathrm{C}\right]$ NMPB and PET: method development and differentiation of tracer delivery from receptor binding. J Cereb Blood Flow Metab 18:619-630. 